\title{
POTENSI KITOSAN KULIT UDANG VANNEMEI (Litopenaeus vannamei) SEBAGAI ANTIBAKTERI TERHADAP Staphylococccus epidermidis, Pseudomonas aeruginosa, Propionibacterium agnes, DAN Escherichia coli DENGAN METODE DIFUSI CAKRAM KERTAS
}

\author{
Suherman B. (), Muhdar Latif ${ }^{*}$, Sisilia Teresia Rosmala Dewi**) \\ *) Program Studi Farmasi Fakultas Farmasi Universitas Indonesia Timur Makassar \\ **) Jurusan Farmasi Poltekkes Kemenkes Makassar
}

\author{
Koresponden \\ Sisilia Teresia Rosmala Dewi \\ Jalan Baji Gau no. 10 Makassar \\ HP. 081355040222 \\ Email : sildewi0310@yahoo.com
}

\begin{abstract}
ABSTRAK
Telah dilakukan penelitian tentang potensi kitosan kulit udang Vannemei (Litopenaeus vannamei) sebagai antibakteri terhadap Staphylococccus epidermidis, Pseudomonas aeruginosa, Propionibacterium agnes, dan Escherichia coli dengan metode difusi cakram kertas dengan tujuan penelitian yaitu untuk mengetahui potensi kitosan kulit udang Vannemei (Litopenaeus vannamei)sebagai antibakteri dalam menghambat pertumbuhan Staphylococccus epidermidis, Pseudomonas aeruginosa, Propionibacterium agnes, dan Escherichia coli dengan menggunakan metode difusi cakram kertas serta menentukan konsentrasi yang paling efektif. Penelitian dilakukan dengan metode difusi agar menggunakan cakram kertas dan media Muller Hilton Agar. Tetrasiklin 30 bpj sebagai kontrol positif dan Asam Asetat 1\% v/v sebagai kontrol negatif. Hasil penelitian menunjukkan kitosan kulit udang Vannemei (Litopenaeus vannamei) memiliki potensi sebagai antibakteri dalam menghambat pertumbuhan Staphylococccus epidermidis, Pseudomonas aeruginosa, Propionibacterium agnes, dan Escherichia coli. Konsentrasi yang paling efektif dalam menghambat pertumbuhan bakteri tersebut yaitu pada konsentrasi kitosan $7 \%$ b/v. Berdasarkan Analisis Varians (ANAVA) menunjukkan adanya perbedaan yang bermakna antar perlakuan $1 \% \mathrm{~b} / \mathrm{v}, 3 \% \mathrm{~b} / \mathrm{v}, 5 \% \mathrm{~b} / \mathrm{v}$ dan $7 \% \mathrm{~b} / \mathrm{v}$ dan kontrol positif (Tetrasiklin) dalam menghambat pertumbuhan bakteri pada taraf $\mathrm{P}=0,000<0,05$.
\end{abstract}

\section{Kata kunci : Potensi, Kitosan, Kulit Udang Vannemei, Antibakteri, Difusi Cakram Kertas}

\section{PENDAHULUAN}

Kitosan adalah suatu polisakarida yang diperoleh dari hasil deasetilasi kitin, yang umumnya berasal dari limbah kulit hewan Crustacea. Kitosan memiliki sifat relatif lebih reaktif dari kitin dan mudah diproduksi dalam bentuk serbuk, pasta, film, serat. Kitosan merupakan bahan bioaktif dan aktivitasnya dapat diaplikasikan dalam bidang farmasi, pertanian, lingkungan industri. Kitosan sebagai bahan bioaktif dapat menghambat pertumbuhan bakteri (Agustin, 2006) dan bahkan senyawa kitosan dapat membunuh bakteri dengan jalan merusak membran sel (Hui, 2004). Aktivitas antibakteri Kitosan dari ekstrak kulit udang dapat menghambat bakteri pembusuk pada makanan lokal yang mengandung bakteri pathogen (Morhsed, 2011).

Udang merupakan komoditas andalan sektor perikanan yang menghasilkan limbah yang cukup banyak. Limbah tersebut berpotensi menjadi pencemar lingkungan. Namun disisi lain, limbah udang yang banyak mengandung kitin tersebut dapat dimanfaatkan untuk pembuatan kitosan. Salah satu pemanfaatan kitosan adalah sebagai antibakteri. Muatan positif kitosan diperkirakan dapat berinteraksi dengan permukaan sel bakteri yang bermuatan negatif, sehingga dapat mengganggu pertumbuhan bakteri (Wulandari N, 2008). 
Di Indonesia udang mengalami proses "cold storage" dimana bagian kepala, ekor, dan kulit dibuang sebagai limbah. Limbah udang ini dapat mencemari lingkungan sehingga perlu dimanfaatkan. Selama ini kulit udang hanya dimanfaatkan sebagai bahan pembuatan kerupuk, terasi, dan suplemen bahan makanan ternak. Padahal 20-30\% limbah tersebut mengandung senyawa kitin yang dapat diubah menjadi kitosan (Haryani dan Budiyati, 2007).

Kitin dalam cangkang udang, terdapat sebagai mukopoli sakarida yang berikatan dengan garam-garam anorganik, terutama kalsium karbonat $\left(\mathrm{CaCO}_{3}\right)$, protein dan lipida termasuk pigmen-pigmen. Oleh karena itu untuk memperoleh kitin dari cangkang udang melibatkan proses-proses pemisahan protein (deproteinasi) dan pemisahan mineral (demineralisasi), sedangkan untuk mendapatkan kitosan dilanjutkan dengan proses pemisahan gugus asetil (deasetilasi). Kitosan sangat berpotensi untuk dijadikan sebagai bahan pengawet makanan, karena kitosan memiliki polikation bermuatan positif sehingga dapat menghambat pertumbuhan mikroba (Wardaniati dan Sugiyani, 2009) dan mampu berikatan dengan senyawa-senyawa yang bermuatan negatif seperti protein, polisakarida, asam nukleat, logam berat (Murtini dkk, 2008).

Kitosan sangat berpotensi untuk dijadikan sebagai bahan antimikroba, karena mengandung enzim lisozim dan gugus aminopolisakarida yang dapat menghambat pertumbuhan mikroba. Enzim lisozim merupakan enzim yang sanggup mencerna dinding sel bakteri sehingga bakteri akan kehilangan kemampuannya menimbulkan penyakit dalam tubuh (hilangnya dinding sel ini menyebabkan sel bekteri akan mati). Kemampuan dalam menekan pertumbuhan bakteri disebabkan bahwa kitosan memiliki polikation bermuatan positif yang mampu menghambat pertumbuhan bakteri (Riski R, et.al, 2015).

Keunggulan kitosan adalah merupakan bahan alami, penggunaan dalam jumlah sedikit (konsentrat), kitosan mempunyai muatan positif yang kuat yang dapat mengikat muatan negatif dari senyawa lain atau berperan sebagai detoksifikasi, menghambat pertumbuhan bakteri, Sifat yang utama kitosan adalah antimikroba. Ada beberapa faktor yang mempengaruhi keaktifan kitosan terhadap mikroba, meliputi sifat - sifat intrinsik maupun ektrinsik kitosan. Aksi kitosan terhadap mikroba lebih cepat kepada fungi dan algae diikuti oleh bakteria (Rabea, 2003).

Kitosan memecah dinding sel dari mikroba sehingga tidak berkembang dan mati. Mekanisme yang berlaku bahwa kitosan mempunyai sifat antimikroba karena kitosan berbentuk membran berpori yang dapat menyerap air pada makanan, sehingga dapat menghambat pertumbuhan mikroba di dalam makanan tersebut. Disamping itu kitosan mempunyai gugus fungsional amina $\left(-\mathrm{NH}_{2}\right)$ yang bermuatan positif sangat kuat yang dapat menarik molekul asam amino bermuatan negatif pembentuk protein dalam mikroba (Sarwono R, 2010).

Salah satu mekanisme yang mungkin terjadi yaitu molekul kitosan memiliki kemampuan untuk berinteraksi dengan senyawa pada permukaan sel bakteri kemudian teradsorbsi membentuk semacam layer (lapisan) yang menghambat saluran transportasi sel sehingga sel mengalami kekurangan substansi untuk berkembang biak dan mengakibatkan matinya sel bakteri (Gemala, 2013).

Menurut Wardaniati, R.A dan Sugiyani S. (2009), kitosan sangat berpotensi untuk dijadikan sebagai bahan antibakteri, karena mengandung enzim lysosim dan gugus aminopolysacharida yang dapat menghambat pertumbuhan bakteri dan efisiensi daya hambat kitosan terhadap bakteri. Menurut Wulandari N, (2008) kitosan kulit udang Windu (Penaeus monodon) $1 \%$ sangat efektif sebagai antibakteri terhadap Staphylococcus aureus, Bacillus substilis, Pseudomonas aeruginosa dan Escherichia coli. Menurut penelitian Killay A, (2013), bahwa kitosan dengan konsentarsi $0,5 \%$ dan $1 \%$ dapat menghambat pertumbuhan bakteri pada ikan asin yang dikeringkan. Pada penelitian sebelumnya Mariska (2012) telah dilakukan isolasi kitosan dari cangkang udang windu dan diuji daya hambatnya terhadap bakteri penyebab jerawat, yaitu Propionibacterium acne. Hasil uji antimikroba menunjukkan bahwa kitosan dari cangkang udang windu memiliki daya hambat minimum pada konsentrasi $0,125 \%$. Pada penelitian selanjutnya Reski Amelia 
(2013) telah dilakukan modifikasi fisik kitosan berupa kitosan nanopartikel lalu diuji daya hambatnya terhadap Propionibacterium acne. Hasil uji daya hambat menunjukkan diameter penghambatan sebesar $15 \mathrm{~mm}$ pada konsetrasi $1 \%$.

Berdasarkan beberapa penelitian sebelumnya, maka peneliti tertarik melakukan suatu penelitian dengan menguji potensi kitosan kulit udang Vannemei (Litopenaeus vannamei) sebagai antibakteri terhadap Staphylococccus epidermidis, Pseudomonas aeruginosa, Propionibacterium agnes, dan Escherichia coli dengan metode difusi cakram kertas. Tujuan dilakukannya penelitian ini agar dapat untuk mengetahui potensi kitosan kulit udang Vannemei (Litopenaeus vannamei)sebagai antibakteri dalam menghambat pertumbuhan Staphylococccus epidermidis, Pseudomonas aeruginosa, Propionibacterium agnes, dan Escherichia coli dengan menggunakan metode difusi cakram kertas serta menentukan konsentrasi yang paling efektif sehingga didapatkan manfaat dalam memperoleh data ilmiah yang dapat menambah informasi tentang limbah kulit udang khususnya kulit udang Vannemei yang dapat dimanfaatkan sebagai kitosan yang berfungsi sebagai bahan antimikroba yang dapat menghambat pertumbuhan mikroorganisme

\section{METODE DAN BAHAN}

\section{Jenis dan Desain Penelitian}

Jenis penelitian ini adalah penelitian eksperimental laboratorium yang merupakan penelitian laboratorium untuk menguji potensi kitosan kulit udang Vannemei (Litopenaeus vannamei) sebagai antibakteri terhadap Staphylococccus epidermidis, Pseudomonas aeruginosa, Propionibacterium agnes, dan Escherichia coli. Desain penelitian yaitu metode difusi agar (disc diffusion) menggunakan cakram kertas, dimana bahan uji yang digunakan adalah ekstrak kitosan kulit udang Vannemei (Litopenaeus vannamei) yang dibuat dengan beberapa variasi konsentrasi.

\section{Tempat dan Waktu Penelitian}

\begin{tabular}{lllr}
\multicolumn{3}{c}{ Penelitian ini dilaksanakan di } \\
Laboratorium & Kimia & Farmasi & dan \\
Laboratorium & Mikrobiologi & Farmasi
\end{tabular}

Universitas Indonesia Timur Makassar. Waktu penelitian dilaksanakan pada bulan Desember 2017 - Januari 2018.

\section{Alat dan Bahan}

Autoklaf, ayakan 100 mesh, cawan petri, inkubator, lamina air flow (LAF), oven pengering, timbangan analitik, thermolyne, waterbath, alat-alat gelas. Sedangkan bahanbahan yang digunakan adalah asam asetat 1\%, Staphylococcus epidermidis, Pseudomonas aeruginosa, Propionibacterium agnes dan Escherichia coli, $\mathrm{HCl} 1 \mathrm{M}, \mathrm{NaCl}$ steril, $\mathrm{NaOH} \mathrm{3 \%}$ dan $50 \%$, Kertas Cakram, Kitosan Kulit Udang Vannamei, Medium Muller Hilton Agar, Medium Nutrien Agar, Tetrasiklin 30 bpj.

\section{Penyiapan Bahan Uji}

1. Pengolahan Bahan Uji

Udang Vannemei (Litopenaeus vannamei) yang didapat dari salah satu pasar ikan di Kota Makassar selanjutnya diambil kulit cangkangnya, kemudian kulit cangkang udangnya dicuci dengan air dan dikeringkan di bawah sinar matahari selama 30 menit. Selanjutnya bahan yang sudah kering diblender sampai menjadi serbuk dan diayak menggunakan ayakan 100 mesh.

2. Pembuatan Kitosan Kulit Udang Vannemei

Pembuatan kitosan kulit udang vanamei mengacu pada prosedur pembuatan kitosan oleh Puspawati dan Simpen (2010) yang mencakup tiga proses yaitu deproteinasi, demineralisasi dan deasetilasi. Proses Deproteinasi dilakukan untuk menghilangkan protein dari kulit udang. Serbuk udang ditimbang dengan berat 200 gr ditambahkan larutan $\mathrm{NaOH} \quad 3 \%$ dilarutkan dalam $1000 \mathrm{ml}$ aquades kemudian dipanaskan menggunakan thermolyne selama 2 jam pada suhu $80^{\circ} \mathrm{C}$ sambil diaduk, kemudian disaring dan dicuci sampai $\mathrm{pH}$ netral dengan air. Proses Demineralisasi dilakukan dengan cara serbuk hasil deproteinasi ditambahkan $\mathrm{HCl} 1 \mathrm{M}(1 \mathrm{M} \mathrm{HCl}=84$ ml) dilarutkan dalam $1.000 \mathrm{ml}$ aquades, dipanaskan selama 1 jam pada suhu $75^{\circ} \mathrm{C}$ sambil diaduk, kemudian disaring dan dicuci dengan air sampai $\mathrm{pH}$ netral dengan air kemudian dikeringkan dalam 
oven suhu $80^{\circ} \mathrm{C}$ selama 24 jam. Tahap ini menghasilkan kitin. Proses terakhir adalah deasetilasi, kitin ditambahkan $\mathrm{NaOH} 50 \%$ dilarutkan dalam $1000 \mathrm{ml}$ aquades, dipanaskan selama 1 jam pada suhu $75^{\circ} \mathrm{C}$ sambil diaduk, kemudian disaring dan dicuci sampai $\mathrm{pH}$ netral atau mendekati $\mathrm{pH}$ 7. Setelah itu dikeringkan dalam oven selama 24 jam, sehingga diperoleh kitosan.

3. Pembuatan Konsentrasi Kitosan

Mengacu pada penelitian Wulandari N, tahun 2008 dengan konsentrasi kitosan yang efektif yaitu $1 \%$. Konsentrasi kitosan $1 \%$ b/v, 3\% b/v, 5\% $\mathrm{b} / \mathrm{v}$ dan $7 \% \mathrm{~b} / \mathrm{v}$ dibuat dengan cara menimbang serbuk kitosan kulit udang Vannemei dalam larutan asam asetat $1 \%$.

Penyiapan Kultur Bakteri dan Pembuatan Larutan Kontrol Positif

1. Peremajaan Kultur Mikroba Uji

Medium Nutrien Agar (NA) yang telah dibuat dimasukkan kedalam tabung-tabung reaksi lalu dimiringkan, setelah medium Nutrient Agar (NA) memadat, diambil masing - masing 1 ose isolat mikroba uji (Staphylococccus epidermidis, Pseudomonas aeruginosa, Propionibacterium agnes dan Escherichia coli) dengan menggunakan ose bulat steril kemudian digoreskan pada masing - masing permukaan medium nutrient agar (NA) lalu inkubasi pada inkubator suhu $37^{\circ} \mathrm{C}$ selama 24 jam.

2. Pembuatan Suspensi Bakteri

Bakteri uji yang berumur 24 jam (Staphylococccus epidermidis, Pseudomonas aeruginosa, Propionibacterium agnes dan Escherichia coli) diambil masing masing 1 ose kemudian disuspensikan dengan larutan fisiologis $\mathrm{NaCl} 0,9 \%$ steril hingga setara dengan larutan standar Mc. Farland 0,5. (Komposisi larutan standar Mc. Farland 0,5 adalah $\mathrm{BaCl}_{2}$ 0,048 $\mathrm{M}$ sebanyak 0,5 $\mathrm{mL}$ dan $\mathrm{H}_{2} \mathrm{SO}_{4}$ 0,18 $\mathrm{M}$ sebanyak 9,5 $\mathrm{mL}$ ).

3. Pembuatan Kontrol Positif (Tetrasiklin)

Larutan kontrol positif dibuat dalam 30 bpj dengan cara ditimbang serbuk Tetrasiklin, dengan penambhan aquadest steril hingga tanda batas.
Pengujian Bahan Uji Kitosan Kulit Udang Vannemei Dengan Metode Difusi Agar

Media Mueller Hilton Agar dituang secara aseptis dimasukkan kedalam cawan petri steril sebanyak $15 \mathrm{ml}$ lalu ditambahkan 0,5 ml suspensi bakteri uji kemudian dihomogenkan dan dibiarkan memadat. Setelah memadat, diletakkan kertas cakram yang sebelumnya kertas cakram tersebut telah dicelupkan kedalam konsentrasi kitosan kulit udang Vannamei dengan konsentrasi $1 \%$ b/v, 3\% b/v, 5\% b/v, dan $7 \%$ $\mathrm{b} / \mathrm{v}$ dan kontrol negatif asam asetat $1 \% \mathrm{~b} / \mathrm{v}$ serta kontrol positif Tetrasiklin $30 \mathrm{bpj}$. Diatur jarak kertas cakram dari pinggir cawan petri minimal $20 \mathrm{~mm}$ kemudian diinkubasi pada suhu $37^{\circ} \mathrm{C}$ dalam inkubator selama 1 x 24 jam. Daerah hambatan yang terbentuk diukur dengan mistar geser. Perlakuan ini dilakukan 3 kali dan diambil rata-ratanya.

\section{Pengamatan dan Pengukuran Diameter Hambatan}

Pengamatan dan pengukuran diameter zona hambatan dilakukan setelah masa inkubasi 1 x 24 jam pada suhu $37^{\circ} \mathrm{C}$. Zona hambatan yang terbentuk pada media diukur dengan menggunakan jangka sorong.

Tabel 1. Kategori penghambatan antimikroba berdasarkan diameter zona hambat menurut Davis and Stout (1971)

\begin{tabular}{cc}
\hline Diameter $(\mathrm{mm})$ & $\begin{array}{c}\text { Respon Hambatan } \\
\text { Pertumbuhan }\end{array}$ \\
\hline$\leq 5 \mathrm{~mm}$ & Lemah \\
$5-10 \mathrm{~mm}$ & Sedang \\
$10-20 \mathrm{~mm}$ & Kuat \\
$\geq 20 \mathrm{~mm}$ & Sangat Kuat \\
\hline
\end{tabular}

Sumber : Ambarwati, 2007.

\section{Analisis Data}

Data diambil dari hasil pengamatan dan hasil pengukuran diameter zona hambatan dari tiap konsentrasi kitosan kulit udang Vannamei beserta kontrol positif dan negatif dan dianalisis secara statistik dengan aplikasi SPSS (Statistical Package for Social Science) for Windows ${ }^{\circledR}$ untuk melihat potensi kitosan kulit udang Vannamei dengan berbagai konsentrasi terhadap pertumbuhan Staphylococccus epidermidis, Pseudomonas aeruginosa, 
Propionibacterium agnes dan Escherichia coli.

\section{HASIL DAN PEMBAHASAN}

\section{Hasil Penelitian}

Hasil penelitian tentang potensi kitosan kulit udang Vannemei (Litopenaeus vannamei) sebagai antibakteri terhadap
Staphylococccus epidermidis, Pseudomonas aeruginosa, Propionibacterium agnes, dan Escherichia coli dengan metode difusi cakram kertas yakni berupa diameter zona hambatan dengan masa inkubasi 1 x 24 jam pada suhu $37^{\circ} \mathrm{C}$ dapat dilihat pada tabel berikut :

Tabel 2. Hasil pengukuran diameter hambatan (mm) kitosan kulit udang Vannemei (Litopenaeus vannamei) terhadap pertumbuhan Staphylococccus epidermidis dengan masa inkubasi $1 \times 24$ jam pada suhu $37^{\circ} \mathrm{C}$.

\begin{tabular}{|c|c|c|c|c|c|c|}
\hline \multirow[t]{2}{*}{ Bakteri Uji } & \multicolumn{6}{|c|}{$\begin{array}{c}\text { Diameter Zona Hambatan (mm) kitosan kulit udang Vannemei } \\
\text { (Litopenaeus vannamei) }\end{array}$} \\
\hline & Kontrol (-) & $1 \% \mathrm{~b} / \mathrm{v}$ & $3 \% \mathrm{~b} / \mathrm{v}$ & $5 \% \mathrm{~b} / \mathrm{v}$ & $7 \% \mathrm{~b} / \mathrm{v}$ & Kontrol (+) \\
\hline \multirow{3}{*}{$\begin{array}{l}\text { Staphylococccus } \\
\text { epidermidis }\end{array}$} & 6,6 & 10,9 & 11,6 & 12,4 & 13,1 & 17,9 \\
\hline & 6,6 & 10,6 & 11,6 & 12,4 & 14,6 & 18,2 \\
\hline & 7,6 & 11,4 & 12,4 & 12,6 & 14,6 & 18,6 \\
\hline Jumlah & 20,8 & 32,9 & 35,6 & 37,4 & 42,3 & 54,7 \\
\hline Rata-rata & 6,93 & 10,96 & 11,86 & 12,46 & 14,10 & 18,23 \\
\hline
\end{tabular}

Sumber : Data Primer 2017 - 2018

Tabel 3. Hasil pengukuran diameter hambatan (mm) kitosan kulit udang Vannemei (Litopenaeus vannamei) terhadap pertumbuhan Pseudomonas aeruginosa dengan masa inkubasi 1 x 24 jam pada suhu $37^{0} \mathrm{C}$.

\begin{tabular}{ccccccc}
\hline & \multicolumn{5}{c}{ Diameter Zona Hambatan (mm) kitosan kulit udang } \\
Bakteri Uji & \multicolumn{5}{c}{ Vannemei (Litopenaeus vannamei) } \\
& Kontrol (-) & $\mathbf{1 \%} \mathbf{b} / \mathbf{v}$ & $\mathbf{3 \%} \mathbf{b} / \mathbf{v}$ & $\mathbf{5 \%} \mathbf{b} / \mathbf{v}$ & $\mathbf{7 \%}$ b/v & $\begin{array}{c}\text { Kontrol } \\
(+)\end{array}$ \\
\hline \multirow{2}{*}{$\begin{array}{c}\text { Pseudomonas } \\
\text { aeruginosa }\end{array}$} & 6,5 & 10,9 & 11,8 & 12,5 & 15,3 & 17,6 \\
\hline Jumlah & 6,4 & 10,9 & 11,8 & 13,5 & 15,0 & 17,6 \\
\hline Rata-rata & $\mathbf{2 0 , 1}$ & 9,9 & 11,5 & 12,5 & 15,6 & 17,5 \\
\hline
\end{tabular}

Sumber : Data Primer 2017 - 2018 
Tabel 4. Hasil pengukuran diameter hambatan (mm) kitosan kulit udang Vannemei (Litopenaeus vannamei) terhadap pertumbuhan Propionibacterium agnes dengan masa inkubasi $1 \mathrm{x}$

\begin{tabular}{|c|c|c|c|c|c|c|}
\hline \multirow{2}{*}{ Bakteri Uji } & \multicolumn{6}{|c|}{$\begin{array}{c}\text { Diameter Zona Hambatan (mm) kitosan kulit udang Vannemei } \\
\text { (Litopenaeus vannamei) }\end{array}$} \\
\hline & Kontrol (-) & $1 \% \mathrm{~b} / \mathrm{v}$ & $3 \% \mathrm{~b} / \mathrm{v}$ & $5 \% \mathrm{~b} / \mathrm{v}$ & $7 \% \mathrm{~b} / \mathrm{v}$ & $\begin{array}{l}\text { Kontrol } \\
(+)\end{array}$ \\
\hline \multirow{3}{*}{$\begin{array}{l}\text { Propionibacterium } \\
\text { agnes }\end{array}$} & 6,5 & 12,5 & 13,5 & 14,5 & 16,6 & 19,8 \\
\hline & 7,0 & 11,7 & 13,3 & 14,1 & 16,6 & 20,6 \\
\hline & 7,5 & 12,5 & 13,0 & 14,5 & 18,6 & 21,6 \\
\hline Jumlah & 21,0 & 36,7 & 39,8 & 43,1 & 51,8 & 62,0 \\
\hline Rata-rata & 7,00 & 12,23 & 13,26 & 14,36 & 17,26 & 20,66 \\
\hline
\end{tabular}

24 jam pada suhu $37^{0} \mathrm{C}$

Sumber : Data Primer 2017 - 2018

Tabel 5. Hasil pengukuran diameter hambatan (mm) kitosan kulit udang Vannemei (Litopenaeus vannamei) terhadap pertumbuhan Escherichia coli dengan masa inkubasi 1 x 24 jam pada suhu $37^{\circ} \mathrm{C}$.

\begin{tabular}{ccccccc}
\hline & \multicolumn{5}{c}{$\begin{array}{c}\text { Diameter Zona Hambatan (mm) } \\
\text { kitosan kulit udang }\end{array}$} \\
Bakteri Uji & Kontrol (-) & $\mathbf{1 \%} \mathbf{b} / \mathbf{v}$ & $\mathbf{3 \%} \mathbf{b} / \mathbf{v}$ & $\mathbf{5 \%} \mathbf{b} / \mathbf{v}$ & $\mathbf{7 \%} \mathbf{b} / \mathbf{v}$ & $\begin{array}{c}\text { Kontrol } \\
(+)\end{array}$ \\
\hline \multirow{2}{*}{ Escherichia coli } & 6,9 & 11,8 & 12,0 & 12,8 & 14,3 & 18,6 \\
& 7,1 & 11,3 & 12,5 & 13,8 & 14,3 & 18,6 \\
& 6,8 & 11,5 & 12,5 & 13,6 & 13,9 & 19,6 \\
\hline \multirow{2}{*}{ Jumlah } & $\mathbf{2 0 , 8}$ & $\mathbf{3 4 , 6}$ & $\mathbf{3 7 , 0}$ & $\mathbf{4 0 , 2}$ & $\mathbf{4 2 , 5}$ & $\mathbf{5 6 , 8}$ \\
\hline Rata-rata & $\mathbf{6 , 9 3}$ & $\mathbf{1 1 , 5 3}$ & $\mathbf{1 2 , 3 3}$ & $\mathbf{1 3 , 4 0}$ & $\mathbf{1 4 , 1 6}$ & $\mathbf{1 8 , 9 3}$ \\
\hline
\end{tabular}

Sumber : Data Primer 2017 - 2018

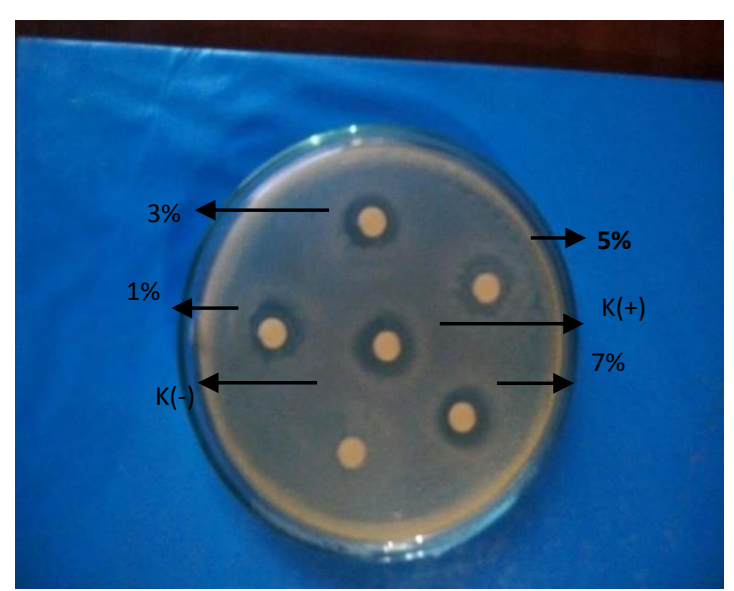

Gambar 1

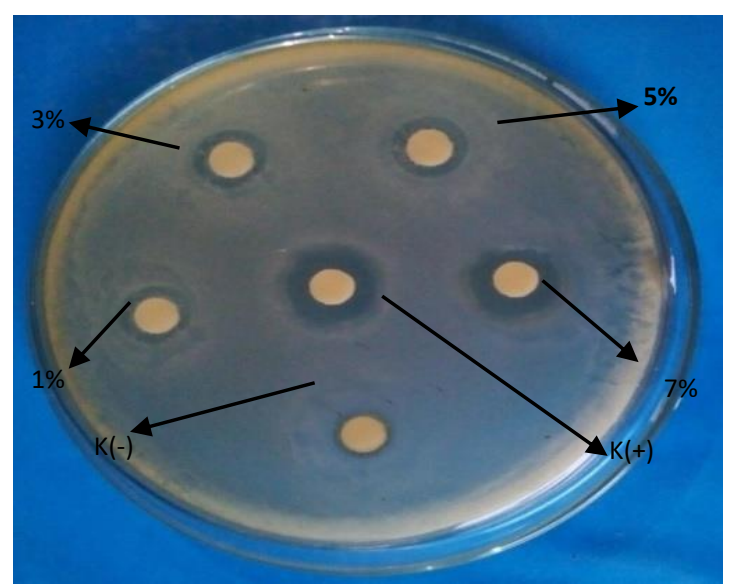

Gambar 2 


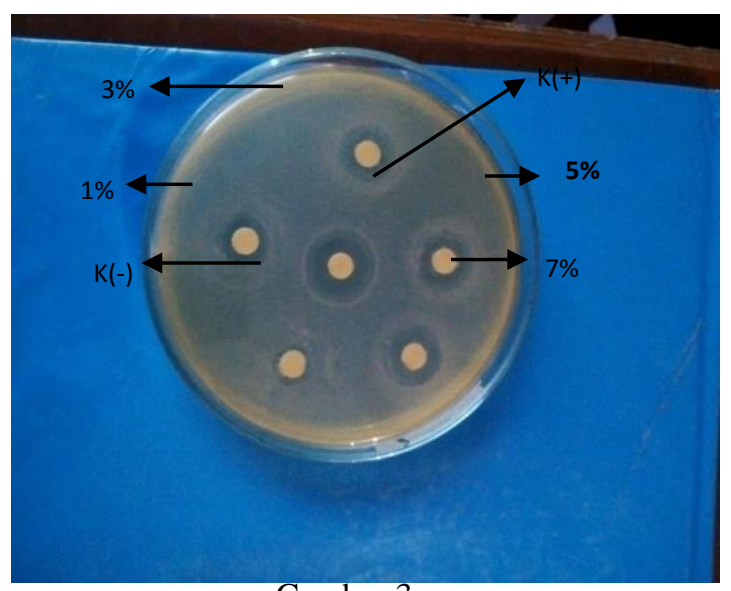

Gambar 3

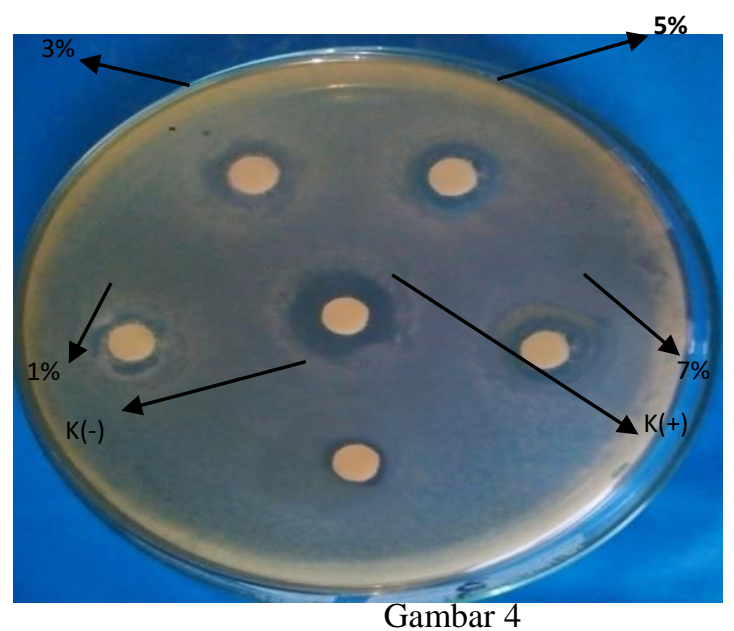

Gambar 4

Gambar 1 : Hasil zona hambatan kitosan kulit udang Vannemei (Litopenaeus vannamei) terhadap pertumbuhan Staphylococccus epidermidis masa inkubasi 1 x 24 jam.

Gambar 2 : Hasil zona hambatan kitosan kulit udang Vannemei (Litopenaeus vannamei) terhadap pertumbuhan Pseudomonas aeruginosa masa inkubasi 1 x 24 jam.

Gambar 3 : Hasil zona hambatan kitosan kulit udang Vannemei (Litopenaeus vannamei) terhadap pertumbuhan Propionibacterium agnes masa inkubasi 1 x 24 jam.

Gambar 4 : Hasil zona hambatan kitosan kulit udang Vannemei (Litopenaeus vannamei) terhadap pertumbuhan Escherichia coli masa inkubasi 1 x 24 jam.

\section{Pembahasan}

Kitosan merupakan bahan bioaktif dan aktivitasnya dapat diaplikasikan dalam bidang perikanan, pertanian, lingkungan industri, kecantikan, farmasi, kesehatan, dan pangan. Kitosan memiliki sifat antimikroba, karena dapat menghambat bakteri patogen dan mikroorganisme pembusuk, termasuk jamur, bakteri gram positif dan bakteri gram negatif. Kitosan merupakan modifikasi senyawa kitin yang banyak terdapat dalam kulit luar hewan golongan Crustaceae seperti udang dan kepiting. Khasiat kitosan sebagai bahan antibakteri dan kemampuannya untuk mengimobilisasi bakteri menjadikan kitosan dapat digunakan sebagai pengawet makanan.

Selama ini limbah kulit udang belum dimanfaatkan secara maksimal, padahal kulit udang dapat dimanfaatkan untuk menghasilkan kitin, kitosan dan glukosamin, yang penggunaannya cukup luas dalam berbagai bidang dan tentunya mempunyai nilai tambah yang jauh lebih baik. Limbah yang berupa kepala, kulit, ekor dan kaki udang tersebut memiliki potensi untuk dimanfaatkan salah satunya adalah kitosan dari kulit udang.
Dalam penelitian ini dilakukan uji potensi kitosan kulit udang Vannemei (Litopenaeus vannamei) sebagai antibakteri terhadap Staphylococccus epidermidis, Pseudomonas aeruginosa, Propionibacterium agnes, dan Escherichia coli dengan metode difusi cakram kertas dengan tujuan penelitian untuk mengetahui potensi kitosan kulit udang Vannemei sebagai antibakteri dalam menghambat pertumbuhan Staphylococccus epidermidis, Pseudomonas aeruginosa, Propionibacterium agnes, dan Escherichia coli dengan menggunakan metode difusi cakram kertas serta menentukan konsentrasi yang paling efektif.

Pada pengujian ini bahan yang digunakan adalah kitosan yang diperoleh dari kulit udang Vannemei (Litopenaeus vannamei) yang didapatkan dari salah satu pasar ikan di Kota Makassar tetapi sebelum didapatkan kitosan terlebih dahulu dilakukan pengolahan, dimana udang tersebut diambil kulit cangkangnya, kemudian kulit cangkang udang tersebut dicuci dengan air dan dikeringkan di bawah sinar matahari selama 30 menit selanjutnya bahan yang sudah kering diblender sampai menjadi serbuk dan 
diayak menggunakan ayakan 100 mesh. Selanjutnya dibuat kitosan dengan mencakup tiga proses yaitu deproteinasi, demineralisasi dan deasetilasi.

Pengujian konsentrasi kitosan kulit udang Vannemei terhadap beberapa bakteri tersebut dengan menggunakan media Mueller Hilton Agar secara aseptis kedalam cawan petri steril sebanyak $15 \mathrm{ml}$ lalu ditambahkan $0,5 \mathrm{ml}$ suspensi bakteri kemudian dihomogenkan dan dibiarkan memadat. Selanjutnya diletakkan kertas cakram yang sebelumnya kertas cakram tersebut telah dicelupkan kedalam konsentrasi kitosan kulit udang Vannamei dengan konsentrasi $1 \% \mathrm{~b} / \mathrm{v}, 3 \% \mathrm{~b} / \mathrm{v}, 5 \% \mathrm{~b} / \mathrm{v}$, dan $7 \%$ b/v dan kontrol negatif asam asetat $1 \% \mathrm{v} / \mathrm{v}$ serta kontrol positif Tetrasiklin 30 bpj kemudian diinkubasi pada suhu $37^{\circ} \mathrm{C}$ dalam inkubator selama 1 x 24 jam. Daerah hambatan yang terbentuk diukur dengan mistar geser untuk mendapatkan ukuran daya hambat $(\mathrm{mm})$ dari tiap - tiap konsentrasi kitosan kulit udang Vannamei tersebut.

Hasil pengukuran diameter hambatan $(\mathrm{mm})$ potensi kitosan kulit udang Vannemei (Litopenaeus vannamei) sebagai antibakteri terhadap pertumbuhan Staphylococccus epidermidis dengan masa inkubasi 1 x 24 jam pada suhu $37^{0} \mathrm{C}$ didapatkan jumlah zona hambat seperti yang terdapat pada hasil Diagram Column (Gambar 5.). Hasil hasil pengukuran diameter hambatan $(\mathrm{mm})$ kitosan kulit udang terhadap pertumbuhan Escherichia coli dapat dilihat pada uji statistik menggunakan SPSS (Statistikal Product and Service Solutions), dimana data hasil yang didapatkan terdistribusi Normal $(\mathrm{P}>0,05)$ dan homogen pada taraf $\mathrm{P}=0.106>0.05$ dan berdasarkan Analisis Varians (ANAVA) menunjukkan adanya perbedaan yang bermakna antar perlakuan $1 \% \mathrm{~b} / \mathrm{v}, 3 \% \mathrm{~b} / \mathrm{v}$, $5 \%$ b/v dan $7 \%$ b/v dalam menghambat pertumbuhan Staphylococccus epidermidis pada taraf $\mathrm{P}=0,000<0,05$.

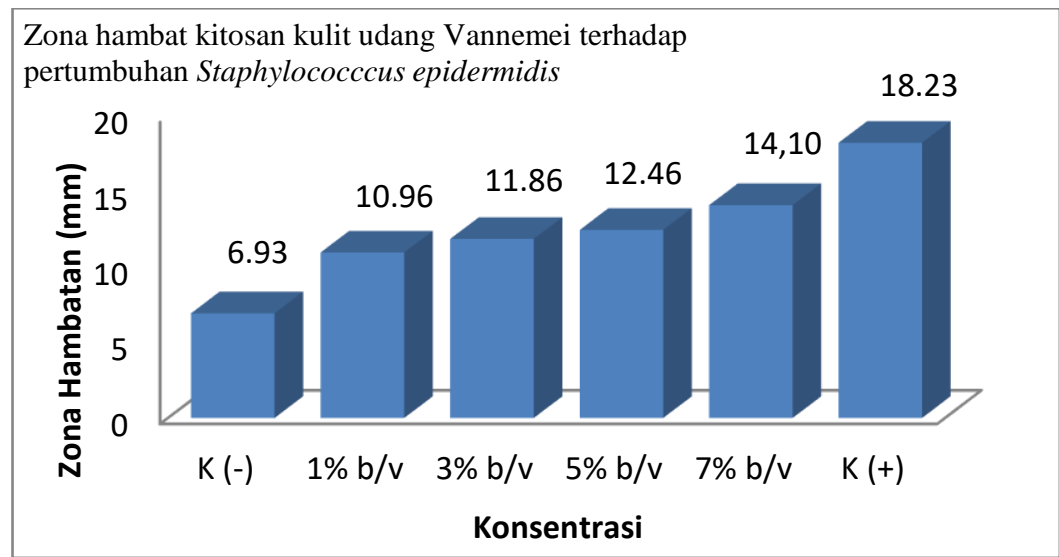

Konsentrasi

Hasil pengukuran diameter hambatan (mm) potensi kitosan kulit udang Vannemei (Litopenaeus vannamei) sebagai antibakteri terhadap pertumbuhan Pseudomonas aeruginosa dengan masa inkubasi 1 x 24 jam pada suhu $37^{\circ} \mathrm{C}$ didapatkan jumlah zona hambat seperti yang terdapat pada hasil Diagram Column (Gambar 6.). Hasil pengukuran diameter hambatan kitosan kulit udang Vannemei terhadap pertumbuhan Pseudomonas aeruginosa dapat dilihat pada uji statistik menggunakan SPSS (Statistical Package for Social Science) for Windows ${ }^{\circledR}$, dimana data hasil yang didapatkan terdistribusi Normal $(\mathrm{P}>0,05)$ dan homogen pada taraf $\mathrm{P}=0.126>0.05$ dan berdasarkan Analisis Varians (ANAVA) menunjukkan adanya perbedaan yang bermakna antar perlakuan $1 \% \mathrm{~b} / \mathrm{v}, 3 \% \mathrm{~b} / \mathrm{v}, 5 \% \mathrm{~b} / \mathrm{v}$ dan $7 \%$ $\mathrm{b} / \mathrm{v}$ dalam menghambat pertumbuhan Pseudomonas aeruginosa pada taraf $\mathrm{P}=$ $0,000<0,05$. 


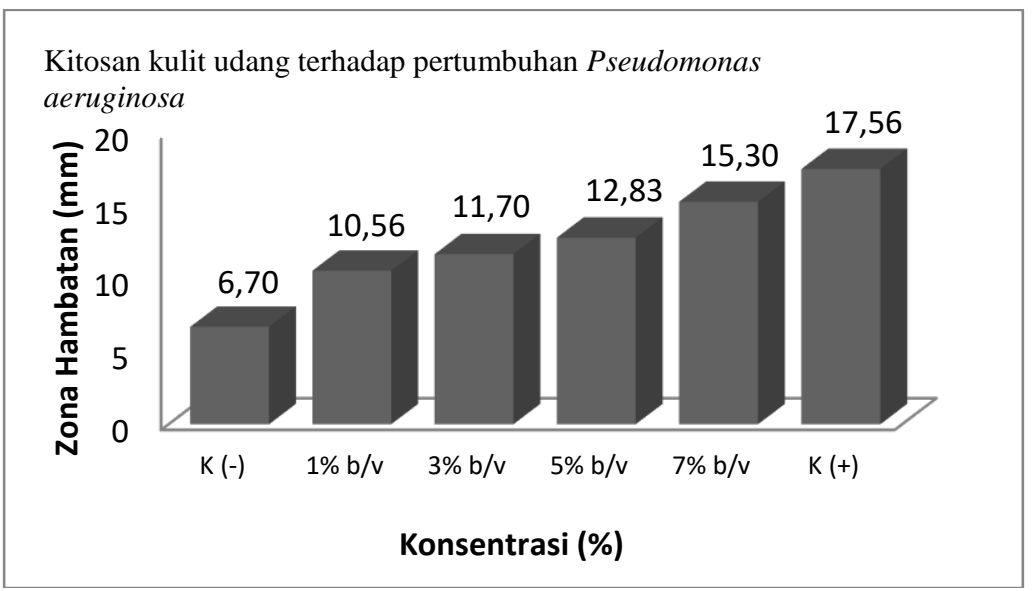

Gambar 6.

Untuk hasil pengukuran diameter hambatan (mm) potensi kitosan kulit udang Vannemei (Litopenaeus vannamei) sebagai antibakteri terhadap pertumbuhan Propionibacterium agnes dengan masa inkubasi 1 x 24 jam pada suhu $37^{\circ} \mathrm{C}$ didapatkan jumlah zona hambat seperti yang terdapat pada hasil Diagram Column (Gambar 7.). Hasil hasil pengukuran diameter hambatan ( $\mathrm{mm}$ ) kitosan kulit udang terhadap pertumbuhan Escherichia coli dapat dilihat pada uji statistik menggunakan SPSS (Statistikal Product and Service Solutions), dimana data hasil yang didapatkan terdistribusi Normal $(\mathrm{P}>0,05)$ dan homogen pada taraf $\mathrm{P}=0.054>0.05$ dan berdasarkan Analisis Varians (ANAVA) menunjukkan adanya perbedaan yang bermakna antar perlakuan $1 \% \mathrm{~b} / \mathrm{v}, 3 \% \mathrm{~b} / \mathrm{v}$, $5 \% \mathrm{~b} / \mathrm{v}$ dan $7 \% \mathrm{~b} / \mathrm{v}$ dalam menghambat pertumbuhan Propionibacterium agnes pada taraf $\mathrm{P}=0,000<0,05$.

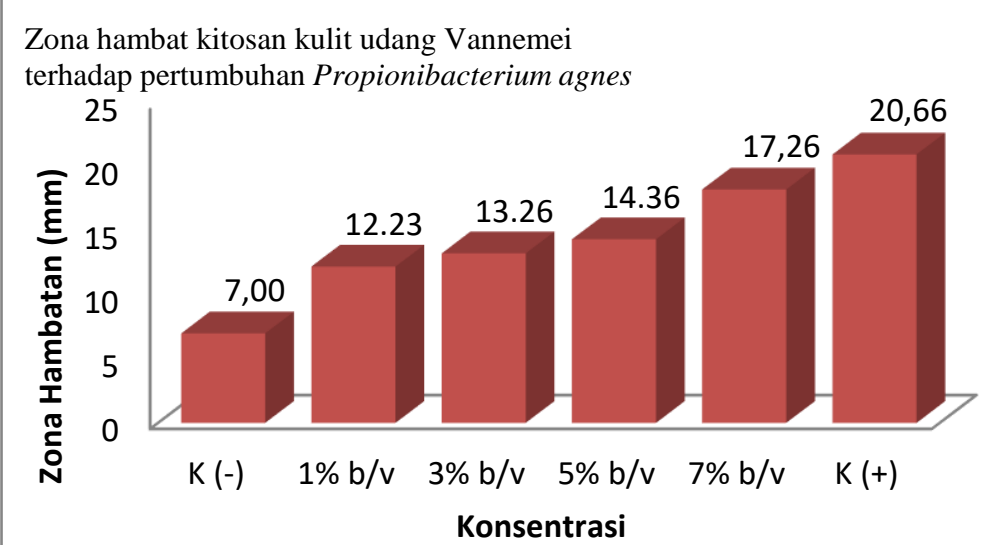

Untuk hasil pengukuran diameter hambatan $(\mathrm{mm})$ potensi kitosan kulit udang Vannemei (Litopenaeus vannamei) sebagai antibakteri terhadap pertumbuhan Escherichia coli dengan masa inkubasi $1 \mathrm{x}$ 24 jam pada suhu $37^{0} \mathrm{C}$ didapatkan jumlah zona hambat seperti yang terdapat pada hasil Diagram Column (Gambar 8.). Hasil hasil pengukuran diameter hambatan ( $\mathrm{mm})$ kitosan kulit udang terhadap pertumbuhan Escherichia coli dapat dilihat pada uji

\section{Gambar 7.}

statistik menggunakan SPSS (Statistikal Product and Service Solutions), dimana data hasil yang didapatkan terdistribusi Normal $(\mathrm{P}>0,05)$ dan homogen pada taraf $\mathrm{P}=0.067$ $>0.05$ dan berdasarkan Analisis Varians (ANAVA) menunjukkan adanya perbedaan yang bermakna antar perlakuan $1 \% \mathrm{~b} / \mathrm{v}, 3 \%$ $\mathrm{b} / \mathrm{v}, 5 \% \mathrm{~b} / \mathrm{v}$ dan $7 \% \mathrm{~b} / \mathrm{v}$ dalam menghambat pertumbuhan Escherichia coli pada taraf $\mathrm{P}=$ $0,000<0,05$ 


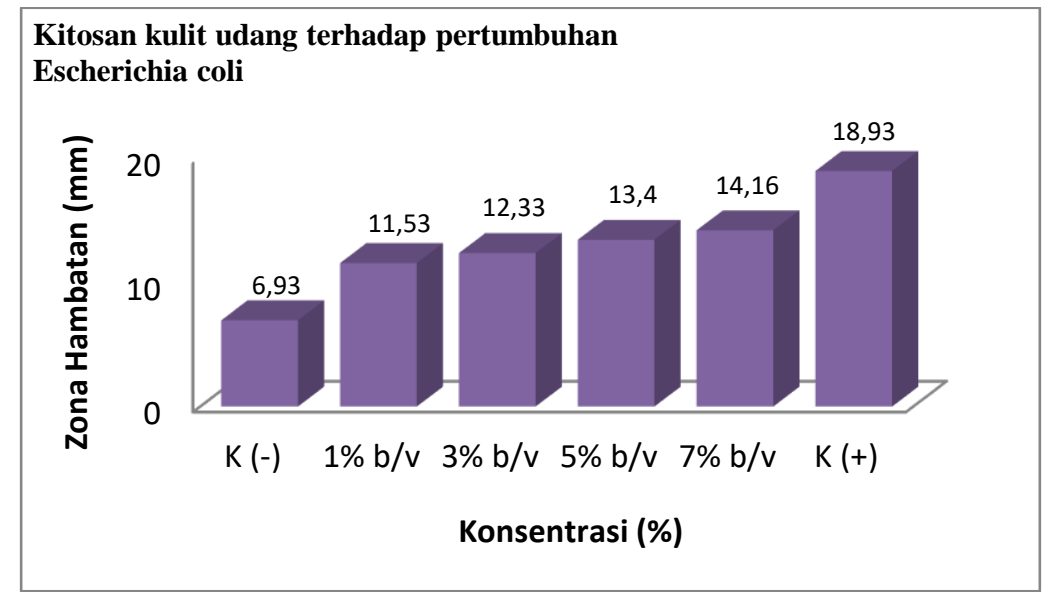

Gambar 8.

Hasil yang diperoleh dapat diketahui bahwa kitosan kulit udang Vannemei (Litopenaeus vannamei) efektif sebagai antibakteri dalam menghambat pertumbuhan Staphylococccus epidermidis, Pseudomonas aeruginosa, Propionibacterium agnes maupun Escherichia coli. dengan masa inkubasi 1 x 24 jam. Ini dimungkinkan komponen - komponen kimia yang terdapat pada kitosan kulit udang Vannemei seperti gugus fungsional amina $\left(-\mathrm{NH}_{2}\right)$ yang bermuatan positif serta memiliki pasangan elektron bebas yang dapat menarik mineral $\mathrm{Mg}^{2+}$ yang terdapat pada ribosom dan mineral $\mathrm{Ca}^{2+}$ yang terdapat pada dinding sel bakteri Propionibacterium agnes yang membentuk ikatan kovalen koordinasi.

Hasil yang didapatkan dari penelitian ini juga didukung dari beberapa penelitian sebelumnya yaitu pada penelitian Wardaniati, R.A dan Sugiyani S. tahun 2009 dalam penelitiannya mengemukakan bahwa kitosan sangat berpotensi untuk dijadikan sebagai bahan antibakteri, karena mengandung enzim lysosim dan gugus aminopolysacharida yang dapat menghambat pertumbuhan bakteri dan efisiensi daya hambat kitosan terhadap bakteri. Pada penelitian Wulandari N, tahun 2008 mengemukakan bahwa kitosan kulit udang Windu (Penaeus monodon) $1 \%$ sangat efektif sebagai antibakteri. Menurut penelitian Killay A, tahun 2013 mengemukakan bahwa kitosan dengan konsentarsi $0,5 \%$ dan $1 \%$ dapat menghambat pertumbuhan bakteri pada ikan asin yang dikeringkan. Kitosan secara umum merupakan bahan alami serta penggunaan dalam jumlah sedikit (konsentrat), kitosan juga mempunyai muatan positif yang kuat yang dapat mengikat muatan negatif dari senyawa lain atau berperan sebagai detoksifikasi, menghambat pertumbuhan bakteri karena sifat yang utama kitosan adalah sebagaii antimikroba.

\section{PENUTUP}

Kesimpulan

1. Kitosan kulit udang Vannemei (Litopenaeus vannamei) memiliki potensi sebagai antibakteri dalam menghambat pertumbuhan Staphylococcus epidermidis, Pseudomonas aeruginosa, Propionibacterium agnes, dan Escherichia coli. Konsentrasi yang paling efektif dalam menghambat pertumbuhan bakteri tersebut yaitu pada konsentrasi kitosan 7\% b/v.

2. Berdasarkan Analisis Varians (ANAVA) menunjukkan adanya perbedaan yang bermakna antar perlakuan $1 \% \mathrm{~b} / \mathrm{v}, 3 \%$ $\mathrm{b} / \mathrm{v}, 5 \% \mathrm{~b} / \mathrm{v}$ dan $7 \% \mathrm{~b} / \mathrm{v}$ dan kontrol positif (Tetrasiklin) dalam menghambat pertumbuhan bakteri pada taraf $\mathrm{P}=0,000$ $<0,05$.

\section{Saran}

Perlu dilakukan pengujian lebih lanjut tentang formulasi kitosan kulit udang Vannemei (Litopenaeus vannamei) dalam bentuk sediaan cream dan disarankan pula untuk meneliti lebih lanjut tentang kitosan dari kulit hewan golongan Crustaceae jenis lain. 


\section{DAFTAR PUSTAKA}

Agustini, T.W. dan Sedjati, S., 2006. The Effect of Chitosan Concentration and Storage Time on the Quality of Salted - Dried Anchovy (Stolephorus heterolobus). Journal of Coastal Development, 10 (2): 6371.

Ambarwati. 2007. Efektivitas Zat Antibakteri Biji Mimba (Azadirchta indica) untuk menghambat Pertumbuhan Salmonella thyposa dan Staphylococcus aureus. Journal of Biodiversitas. V. $8: 3$

Gemala A. M, Suwondo, Elya F, 2013. Efektivitas Chitosan Kulit Udang Terhadap Nilai Gizi Tahu Sebagai Sumber Belajar Biologi dengan Model Pembelajaran DI(Direct Intruction) Pada Konsep Bioteknologi. Repository.Available as PDF File; p.2.

Hanafi M, 2000. Pemanfaatan Kulit Udang Untuk Pembuatan Kitosan Dan Glukosamin, JKTI, Vol. 10, No. 12, Puslitbang Kimia Terapan (P3KT) - LIPI Kawasan PUSPIPTEK.

Hafdani, F.N. and Sadeghinia. N., 2011. A Review on Application of Chitosan as a Natural Antimicrobial. World Academy of Science. Engineering and Technology.

Haryani, K. dan Budiyati. 2010. Khitosan dari Kulit Udang untuk Mengadsorbsi Logam Krom (Cr6+) dan Tembaga ( $\mathrm{Cu}$ ) (online), Vol. 11 No. 2, Artikel F.MIPA Undip.

Henriette, M.C. Azeredo, de Britto, D. and Assis., O.B.G., 2010. Chitosan Edible Films and Coating Review, Embrapa Tropical Agroindustry, Fortaleza, CE, Brazil, ISBN 978-1-61728-831-9.

Hui Liu, Yumin Du, Xiaohui Wang, Liping Sun, 2004. Chitosan Kills Bacteria through Cell Membrane Damage. International Journal of Food Microbiology. 95:147-155.

Isnawati N, et.al, 2015. Pembuatan Kitosan Dari Kulit Udang Putih (Penaeus merguiensis) Dan Aplikasinya Sebagai Pengawet Alami Untuk Udang Segar, Jurnal Teknologi Agro-Industri Vol. 2 No.2, Jurusan Teknologi Industri Pertanian, Politeknik Negeri Tanah Laut

Killay A, 2013. Kitosan Sebagai Antibakteri Pada Bahan Pangan Yang Aman Dan Tidak Berbahaya, Jurusan Biologi, FMIPA Universitas Pattimura.

Mariska, 2012. .Isolasi Kitosan dari Limbah Cangkang Udang Windu (Paneus monodon) dan Uji Aktivitas Antibakteri Terhadap Propionibacterium acne (skripsi). Makassar: Sekolah Tinggi Ilmu Farmasi.

Morhsed, A., Bashir, A., Khan, M.H. dan Alam, M.K., 2011. Antibacterial Activity of Shrimp Chitosan Against some Local Food Spoilagebacteria and Food Borne Pathogens. Bangladesh Journal Microbiol.

Murtini, J.T, Dwiyitno dan Yusma. 2008. Penurunan Kandungan Kolesterol pada Cumi-cumi dengan Kitosan Larut Asam dan Pengepresan. Prosiding Seminar Nasional Tahunan V Hasil Kelautan Tahun 2008. Jakarta.

Puspawati NM dan Simpen IN. 2010. Optimasi Deasetilasi Kitin Dari Kulit Udang Menjadi Kitosan Melalui Variasi Konsentrasi $\mathrm{NaOH}$. Universitas Udayana. Jurnal kimia 4(1) Januari 2010:7990.

Rabea, E.L. et al, 2003. Chitosan as antimicrobial agent : applications and mode of action.

Biomacromolecules, NovemberDesember.

Reski,A, 2013. Uji Aktivitas Antibakteri Nano Partikel Kitosan dari Cangkang Udang Windu (Penaeus monodon Fab.) Terhadap Bakteri Propionibacterium Acnes (skripsi). Makassar: Sekolah Tinggi Ilmu Farmasi. 
Riski R, et.al, 2015. Formulasi Krim Anti Jerawat Dari Nanopartikel Kitosan Cangkang Udang Windu (Penaeusmonodon), JF FIK UINAM Vol.3 No.4,STIFA Makassar.

Sarwono R, 2010. Pemanfaatan Kitin / Kitosan Sebagai Bahan Antimikroba, Pusat Penelitian Kimia, Lembaga IImu Pengetahuan Indonesia.
Wulandari N, 2008. Uji Antibakteri Kitosan Dari Kulit Udang Windu (Penaeus monodon) Dengan Metode Difusi Cakram Kertas, Seminar Tugas Akhir S1 Jurusan Kimia FMIPA UNDIP , Jurusan Kimia UNDIP.

Wardaniati, R.A dan Sugiyani S. 2009. Pembuatan Chitosan dari Kulit Udang dan Aplikasinya untuk Pengawetan Bakso. Makalah Penelitian, UNDIP. Diakses tanggal 02 Agustus 2017. 